\title{
The Implemention of Virtual Laboratory PhET Guided Discovery Learning on Students' Achievement: Dynamic Electricity Topic
}

\author{
Fathiah Alatas a, Hasian Pohan ${ }^{a}$, Ahda Sulukin Nisa ${ }^{c}$ \\ a,b,c Syarif Hidayatullah State Islamic University Jakarta, Jl. Ir. H. Djuanda 95, Ciputat, Indonesia \\ Corresponding e-mail: fathiah.alatas@uinjkt.ac.id
}

\begin{abstract}
Dynamic electricity was considered as abstract concepts, needs experimental study. This research tries to apply learning in a virtual laboratory PhET by guided discovery learning where students build their own knowledge, contextual and interactive. Methods used quasi experimental design with non-equivalent control group. Results of the study showed a positive impact on the Group of medium and high IQ showed a significant effect of virtual laboratory PhET in guided discovery learning model. There is no effect for Low IQ groups. Therefore this study has added practical and theoretical to consider to teach abstract concepts in physics.
\end{abstract}

Keywords: $\quad$ Guided Discovery, PhET, dynamic electricity

\section{INTRODUCTION}

Education is one of the areas affected by the positive impact of technological developments of the $21 \mathrm{st}$ century, therefore the ICT (information Communication Technologies) gets into the main elements, used in education. Application of the technologies used in the field of education such as elearning, distance learning, virtual learning and virtual classroom (Ahmed \& Hasegawa, 2014). Media computer makes the whole subject matter more quickly accepted by students and attracting their interest to learn as well (Gundogdu, et.al, 2011). Several teachers have already begun using a range of technologies to enhance the effectiveness of the process of learning and teaching (Kriek \& Stols, 2010).

Up to now, the process of teaching and learning in physics is still presented in groups of formulas (Wegener et.al, 2012). The abstract concept of Physics makes it difficult to be visualized the physical process display or directly through activities in the real Labs. One of the concepts of physics is the electricity. Electricity is invisible where we can't see the movement of the electrons (electrical charge carriers) on the wire, as well as difficult to learn and to be taught for real (Korganci et.al, 2014). The difficulty of this one utilizes a computer to simulate a simple electric circuit in meaningful learning for students (Dorneles et.al, 2010). Utilizing the computer to simulate something complicated is called virtual laboratory (Mahanta \& Sarma, 2012). Simulation and computer models can help students to understand various concepts of abstract science (Sarabando et.al, 2014; Pfefferova 2015; Tolga, 2011; Bajpai. 2015). Virtual Laboratories made students got experience as if a real laboratory experiments (Martinez et.al, 2011). Virtual laboratory PhET is interactive, contextual and usage calculation simulation effectively to help students understand abstract concepts (Supurwoko et.al, 2016). Virtual laboratory PheT make students exploration as well as the activity of scientists, thus they can learn more and more about a concept of Science (Adams, 2010). According to Ajredini et.al, (2014), there is no significant difference between knowledge gained through real laboratory and through laboratory PhET.

The use of virtual laboratory PheT is combined to pedagogic teacher so learning process is more guidable (Sarabando et.al, 2014; Wieman et.al, 2010). One of the learning models are suitable for 
attracting students actively participate in learning and learning outcomes increased is guided discovery learning model (Shien \& Yu, 2016; Saeful bahri, 2015). Guided discovery learning that recommended in physics learning helps students create, integrate, and generalize knowledge through problem-solving with constructivist learning prepared materials (Abdisa, 2012). Based on the above explanation, this research aims to implement a virtual laboratory PheT in guided discovery learning model on student's learning outcome of dynamic electricity concept.

\section{METHODOLOGY}

The research method was quasi experiment design with non-equivalent control group design. The population of the research was the whole grade $\mathrm{X}$ senior high school (HIGH SCHOOL) Paradigm Mauk Tangerang Regency, where the school was supported by Computer Assisted Instruction (CAI). The teachers tend to use the Power Point program. Currently power point become a standard technology for public school teaching.

Sample selection technique namely purposive sample. Research was conducted in two classes. Class $\mathrm{X} 2$ and X3 classes, each class contains 23 students. $\mathrm{X} 2$ was experiment class X3 was control class. Experiment Class used virtual laboratorium PheT guided discovery learning model to learn. Grade control used conventional methods. The students of class X2 and X3 are divided into 3 groups based on the level of IQ. IQ groups are low IQ groups (students have a low IQ), medium-sized groups (students have common IQ) and high-IQ groups (students have a high IQ). The instruments that used to obtain data is the cognitive tests. Cognitive test aims to find out the increasing cognitive ability in the cognitive level $\mathrm{C} 1$ (recall), C2 (comprehend), C3 (apply), and C4 (analyse). The data were analysed by using the $\mathrm{N}$ Gain test equation 1.

$$
N-\text { Gain }=\frac{\text { posttest }- \text { pretest }}{100-\text { pretest }}
$$

Measurement of cognitive ability is obtained from the results of a pre-test and post-test. Interpretation of $\mathrm{N}$ Gain boost test result is $00.3 \mathrm{G}<$ category $<$ low, 0.3 $\leq \mathrm{G}$ medium category $0.7<$ and $0.7<\mathrm{G}$ of high category (Ridwan \& Akdon, 2013). Prerequisites normality test using the Kolmogorov Shapiro-Wilk and homogeneity test (test Levene). If the data are normal and homogeneous, test hypotheses use testing $\mathrm{T}$. If data is not normal and homogeneous, the hypothesis test use the Mann-Whitney test. Level of significance is $5 \%$.

\section{RESULT AND DISCUSSION}

Before giving treatment, firstly doing pre-test to determine experiment and controls class. From the whole class X with a total of four classes. Class X3 has the highest average rating, so X3 would be control class and X2 was made as an experiment class. Pretest results in analysis with Kolmogorov-Shapiro Wilk normality test showed in Table 1 .

Table 1 Normality Pre-test result

\begin{tabular}{|c|c|c|c|c|}
\hline \multirow{2}{*}{$\begin{array}{c}\text { IQ } \\
\text { Group }\end{array}$} & \multicolumn{2}{|c|}{ Experiment Class } & \multicolumn{2}{c|}{ Control Class } \\
\cline { 2 - 5 } & $\begin{array}{c}\text { Significa } \\
\text { nce }\end{array}$ & $\begin{array}{c}\text { Iinformati } \\
\text { on }\end{array}$ & $\begin{array}{c}\text { Significan } \\
\text { ce }\end{array}$ & Information \\
\hline Low & 0,200 & Normal & 0,200 & Normal \\
\hline Medium & 0,200 & Normal & 0,002 & Not normal \\
\hline High & 0,200 & Normal & 0,200 & Normal \\
\hline
\end{tabular}

Students were given a treatment with assisted discovery guided learning virtual laboratory PhET. While the class control using conventional methods. End of learning all students did post-test. Post-test results are analysed with Kolmogorov-Shapiro Wilk normality test on Table 2:

Table 2 Normality Post-test Result

\begin{tabular}{|c|c|c|c|c|}
\hline \multirow{2}{*}{ IQ Group } & \multicolumn{2}{|c|}{ Experiment Class } & \multicolumn{2}{c|}{ Control Class } \\
\cline { 2 - 5 } & $\begin{array}{c}\text { Significan } \\
\text { ce }\end{array}$ & $\begin{array}{c}\text { Informati } \\
\text { on }\end{array}$ & $\begin{array}{c}\text { Significan } \\
\text { ce }\end{array}$ & Information \\
\hline Low & 0,200 & Normal & 0,200 & Normal \\
\hline Medium & 0,200 & Normal & 0,160 & Normal \\
\hline High & 0,163 & Normal & 0,133 & Normal \\
\hline
\end{tabular}

Pre-test and post-test data then are tested in homogeneous test to know which data homogeneous or heterogeneous. Its homogeneity test with Levene test in Table 3:

Table 3 Homogeneity Pre-test and Post-test result

\begin{tabular}{|c|c|c|c|c|}
\hline \multirow[b]{2}{*}{$\begin{array}{c}\text { IQ } \\
\text { Group }\end{array}$} & \multicolumn{2}{|c|}{ Pre-test } & \multicolumn{2}{|c|}{ Post-tests } \\
\hline & $\begin{array}{c}\text { Significa } \\
\text { nce }\end{array}$ & $\begin{array}{c}\text { Informatio } \\
n\end{array}$ & $\begin{array}{c}\text { Significa } \\
\text { nce }\end{array}$ & $\begin{array}{c}\text { Informati } \\
\text { on }\end{array}$ \\
\hline Low & 0,485 & Homogen & 0,032 & Heterogen \\
\hline Medium & 0,052 & Homogen & 0,514 & Homogen \\
\hline High & 0,371 & Homogen & 0,571 & Homogen \\
\hline
\end{tabular}

Pre-test and post-test data are tested on hypothesis test to find out the effects of the treatment given. Such a Hypothesis test results Table 4 below:

Table 4 Hypothesis Pre-test and Post-test result

\begin{tabular}{|c|c|c|c|c|}
\hline \multirow[b]{2}{*}{$\begin{array}{c}\text { IQ } \\
\text { Group }\end{array}$} & \multicolumn{2}{|c|}{ Control Class } & \multicolumn{2}{|c|}{ Experiment Class } \\
\hline & $\begin{array}{c}\text { Significa } \\
\text { nce }\end{array}$ & $\begin{array}{c}\text { Informatio } \\
n\end{array}$ & $\begin{array}{l}\text { Signifi } \\
\text { cance }\end{array}$ & Info \\
\hline Low & 0,032 & $\mathrm{H}_{1}$ accepted & 0,413 & $\mathrm{H}_{1}$ rejected \\
\hline Medium & 0,791 & $\mathrm{H}_{1}$ rejected & 0,002 & $\mathrm{H}_{1}$ accepted \\
\hline High & 0,587 & $\mathrm{H}_{1}$ rejected & 0,026 & $\mathrm{H}_{1}$ accepted \\
\hline
\end{tabular}


Based on table 4, we can see the effect of guided discovery learning model using virtual laboratorium PhET have no effect on students group of low IQ. While the effects of the PhET effect on both groups of medium and high IQ. This is in accordance with the research Ahvan \& Pour (2016) and Laidra et.al, (2007) shows that there is a positive relationship between the intelligence and the accomplishment of learning in students. High low intelligence will affect each other so they can be promoted to the low learning achievement high accomplished students. Virtual laboratory PhET made to student involvement in learning increases (Wieman et.al, 2008). Learning through discovery students can also be active and participate positively in learning as well as the results of their studies increased Shien \& Yu (2016). Student learning outcomes can be seen from the test $\mathrm{N}$-gain in Figure 1 below.

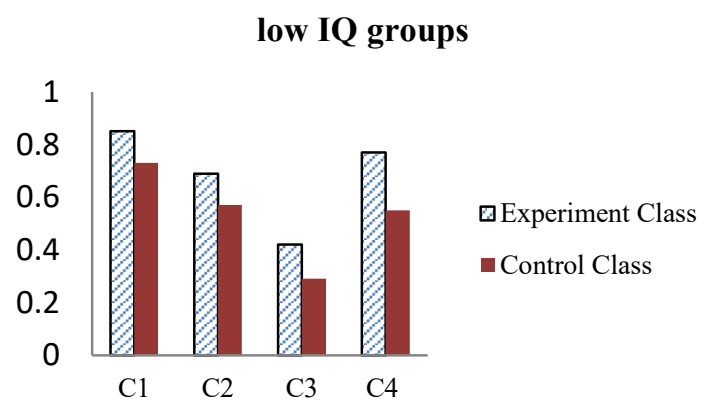

(a)

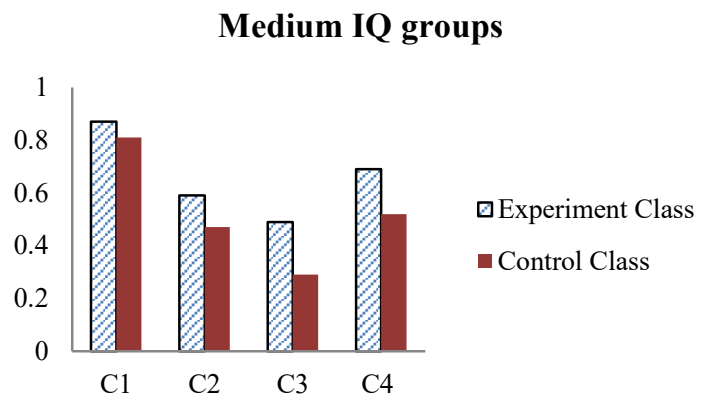

(b)

\section{High IQ groups}

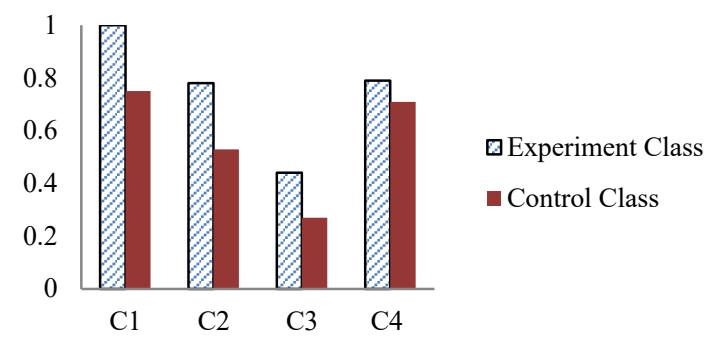

(c)

Figure 1 Test $\mathrm{N}$-gain based on the cognitive aspects (a) low IQ groups (b) Medium IQ groups (c) high IQ group

Based on Figure 1 cognitive Level C1 (recall), experimental classes gain percentage higher than the control class from each group IQ. This is because the simulation PhET was able to give real visualization allowing students easy to recall (Supurwoko, Search, Sarwanto, Sukarmin, and Suparmi, 2013). Cognitive aspects of C4 (analyse), experimental class earn a percentage higher than the control class from each group IQ. This is due to the method of research discoveries can improve students' enthusiasm in learning activities processed (Saeful bahri, 2015). Guided discovery learning recommended in physics learning to help students create, integrate, and generalize knowledge through problem-solving constructivist (Abdisa, 2015).

\section{CONCLUSIONS}

We managed to create a simulation model used in PhET guided discovery learning on the concept of dynamic electricity. The result is just the Group of medium and high IQ were affected while a group of low IQ is not. This means that the virtual laboratorium PhET in the guided discovery does not affect the low group.

\section{ACKNOWLEDGEMENTS}

Acknowledgment to Faculty of Tarbiyah and Teachers Training which has helped provide research funding. Principal School Senior High School (SMA) Paradigma Mauk Tangerang which has assisted research permit. 


\section{REFERENCES}

Abdisa G., Getinet T. (2012). The effect of guided discovery on students' Physics achievement. Lat. Am. J. Phys. Educ. 6(4), 530-537

Adams, W.K. (2010). Student engagement and learning with PhET interactive simulations, IL NUOVO CIMENTO C, 033(3), 21-32

Ahmed M.E., Hasegawa S. (2014). An instructional design model and criteria for designing and developing online virtual labs. International Journal of Digital Information and Wireless Communications (IJDIWC), 4(3), 355-371

Ahvan, Y. R., \& Pour, H. Z. (2016). The correlation of multiple intelligences for the achievement of secondary students. Educational Research and Reviews. 11(4), 141-145

Ajredini F., Izairi N., \& Zajkov O. (2013). Real experiments versus Phet simulations for better high-school students' understanding of electrostatic charging. European Journal of Physics Education, 5 (1), 59-70

Bahri A.S. (2015) The influence of learning model guided findings of student learning outcomes. INTERNATIONAL JOURNAL OF SCIENTIFIC \& TECHNOLOGY RESEARCH , 4 (3), 77-79

Bajpai M., Kumar A. (2015). Effect of virtual laboratory on students' conceptual achievement in physics. International Journal of Current Research, 7(2), 12808-12813

Dorneles P.F.T., Veit E.A., Moreira M.A. (2010). A study about the learning of students who worked with computational modeling and simulation in the study of simple electric circuits. Revista Electrónica de Enseñanza de las Ciencia, 9 (3), 569-595.

Gundogdu, K., Silman, F., \& Ozan, C. (2011). A comparative study on perception of teachers on the use of computers in elementary schools of Turkey and T.R.N.C. International Online Journal of Educational Sciences, 3 (1), 113-137

Korganci N., Mirona C., Dafineia C., \& Antohea S. (2015) The Importance of Inquiry-Based Learning on Electric Circuit Models for Conceptual Understanding. Procedia - Social and Behavioral Sciences, 191, $2463-2468$

Kriek J., Stols G. (2010) Teachers' beliefs and their intention to use interactive simulations in their classrooms. South African Journal of Education, 30, 439-456

Laidra, K., Pullmann, H, \& Allik, J. (2007). Personality and intelligence as predictors of academic achievement: a cross-sectional study from elementary to secondary school.
Personality and Individual Differences. 42(3), 441-451

Mahanta A \& K.K Sarma. (2012). Online resource and ICT-Aided virtual laboratory setup. International Journal of Computer Applications, 52(6), 44-48

Martinez, G., Francisco, L., Naranjo, Angel, L., Perez, Suero, M. I., \& Pardo, P. J. (2011). Comparative study of the effectiveness of three learning environments: Hyper-realistic virtual simulations, traditional schematic simulations and traditional laboratory. Physical Review Special Topics - Physics Education Research, $7(2): 1-12$.

Pfefferova, M.S. (2015). Computer simulations and their Influence on students' understanding of oscillatory motion. Informatics in Education, 14(2), 279-289

Ridwan \& Akdon. (2013) Rumus dan Data Aplikasi Statistika, Bandung: Alfabeta, Cet ke-5

Sarabando C., Cravino J. P., \& Soares, A. A. (2014).Contribution of a computer simulation to students' learning of the physics concepts of weight and mass. Procedia Technology, 13, 112-121

Supurwoko, Cari, Sarwanto, Sukarmin, \& Suparmi. (2016). The Effect of PhET simulation media for physics teacher candidate understanding on photoelectric effect concept. International Journal of Science and Applied Science, 1(1), 34-35

Shieh C., Yu L. (2016). A study on information technology integrated guided discovery instruction towards students learning achievment and learning retention. Eurasia journal of mathematics, science \& technology education, 12(4), 833-842

Tolga GOK. (2011). The Effects of the computer simulations on students' learning in physics education. International Journal on New Trends in Education and Their Implications, 2(2), $104-$ 116

Wieman C.E., Adams W.K., \& Perkins K.K. (2010). Teaching physics using PhET simulations. The Physics Teachers, 48, 225-227

Wegener, M., McIntyre, T. J., \& McGrath, D. (2012). Developing a virtual physics world. Australasian Journal of Educational Technology, 28(3), 504-521.

Wieman C.E, Perkins K.K., \& Adams W.K. (2008). Oersted medal lecture 2007: interactive simulations for teaching physics: What works, what doesn't, and why. American Journal of Physics, 76, 393-399 
Moradi M., Etemad S. Gh., Moheb A. (2010). Synthesis of Magnetic Polyvinyl Alcohol Nanoparticles for Fast Adsorption of $\mathrm{Pb}$ (II) Ions from Water "Proc. of Int. Conf. Nanotech. Fundam. Appl.," Ottawa, Canada, Aug. 4-6, pp. 587-1-587-7.

Vallero D. (2007).“ Fundamentals of Air Pollution $4^{\text {th }}$ edition" Elsevier. 